\title{
心不全症例に対する左房-大腿動脈バイパスによる 経皮的補助循環の有用性
}

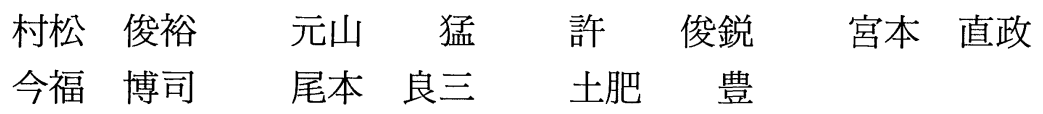

要旨 目的：心不全症例に対する, 左房一大腿動脈バイパス（以下 $\mathrm{AAB}$ と略す）による経皮的左 心補助の有用性を検討すること。方法：心筋梗塞に続発した心停止（3 例）と心原性ショック (2 例)の 5 症例に対して, 独自に開発した経皮的に插入可能な左房脱血カニューレを用いた AAB を 試み，その有用性を右房一大腿動脈バイパス（以下 VAB と略す）と比較した。結果：心停止 3 例 に対して, 最初 VAB 補助を施行した左心不全の克服が困難なため, 平均 16 時間後に 2 例で AAB の移行に成功し, 1 例を 96 時間の心肺補助の後救命できた。移行不成功の 1 例は, 29 時間の VAB 補助を施行したが死亡した。また，1 カ月の intra-aortic balloon pumping (以下IABP と略す) 依存状態の心原性ショックで肺水腫に陥った症例では, 最初から AAB を施行して 3 日間の補助 で左心不全を克服して手術治療に移行できた。VABでは中等度の出血傾向は避け得なかったが, $\mathrm{AAB}$ に移行することで出血傾向を克服できた。結語：心停止に対する迅速な対応はVABが優れ ていたが，長期の左心不全に対する補助としては不十分で，VABのみで早期の回復が期待できな い症例に対しては速やかに AABに移行することが望ましい。

(日救急医会誌 $1993 ; 4: 605-10)$

キーワード：経皮的左心バイパス, 経食道心エコー, 経皮的右房一大腿動脈バイパス, 大動脈内バ ルーンパンピング, 左心不全

一般に，心原性ショックに陥った患者に対して IABP などを駆使して治療を行っており口，その有用 性も広く知られるところである。しかし一方に, IABP を用いても救命できない症例に臨床上遭遇す ることも多く，近年そのような場合には，とくに心 肺蘇生を要するような心筋梗塞に対しての右房一大 腿動脈バイパス型 (以下VAB と略す) の体外循環装 置の緊急的使用効果が広く認められようとしてい る2,3)。

VAB はきわめて強力な補助循環法であり, 右心不 全が主たる重症心不全に対しては, きわめて有効で

Utility of percutaneous cardiopulmonary support by left atrial-aortic bypass in heart failure

埼玉医科大学心臓病センター

著者連絡先：干 350-04 入間郡毛呂山町毛吕本郷 38

原稿受理日：1993 年 3 月 9 日 （93-016）
あるが, 左心系の前負荷軽減についてはそのバイパ ス流量に依存してくることから，VABを用いてもな お効果の得られない場合があることは事実であ る4,5)。このような重症左心不全に対しては左心バイ パス，あるいは両心バイパスを選択すべきと考えら れているが6)，その装着には技術的困難を伴い外科 医の stand-by が必ず必要であった。

今回われわれは, 内科医にも挿入可能な独自の左 房一大腿動脈バイパス（以下 $\mathrm{AAB}$ と略す）を考案し て動物実験を重ね7)，実際にこれを臨床応用したの でこの有用性を報告する。

\section{対象と方法}

いずれも急性心筋梗塞 (以下 AMI と略す) に続発 した心停止 3 例, 心原性ショック 2 例の 5 症例（年 歯命 43〜73 歳) を対象として, 独自に開発した経皮的 


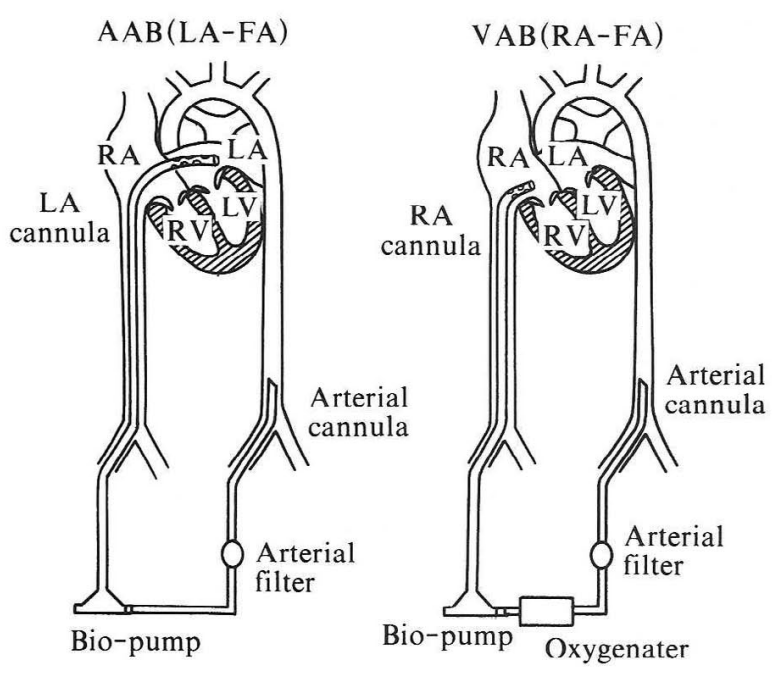

Fig. 1. Diagrams of percutaneous transseptal left atrialaortic bypass and venoarterial bypass.

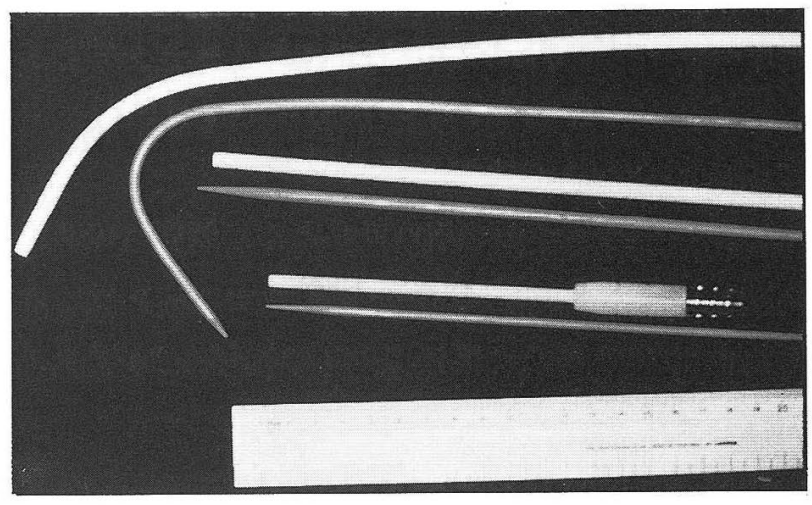

Fig. 2. Cannulas for percutaneous transseptal left atrial-aortic bypass and venoarterial bypass. Upper: Left atrial cannula and its stylet. Middle: Right atrial cannula and its stylet. Lower: Femoral arterial cannula and its stylet.

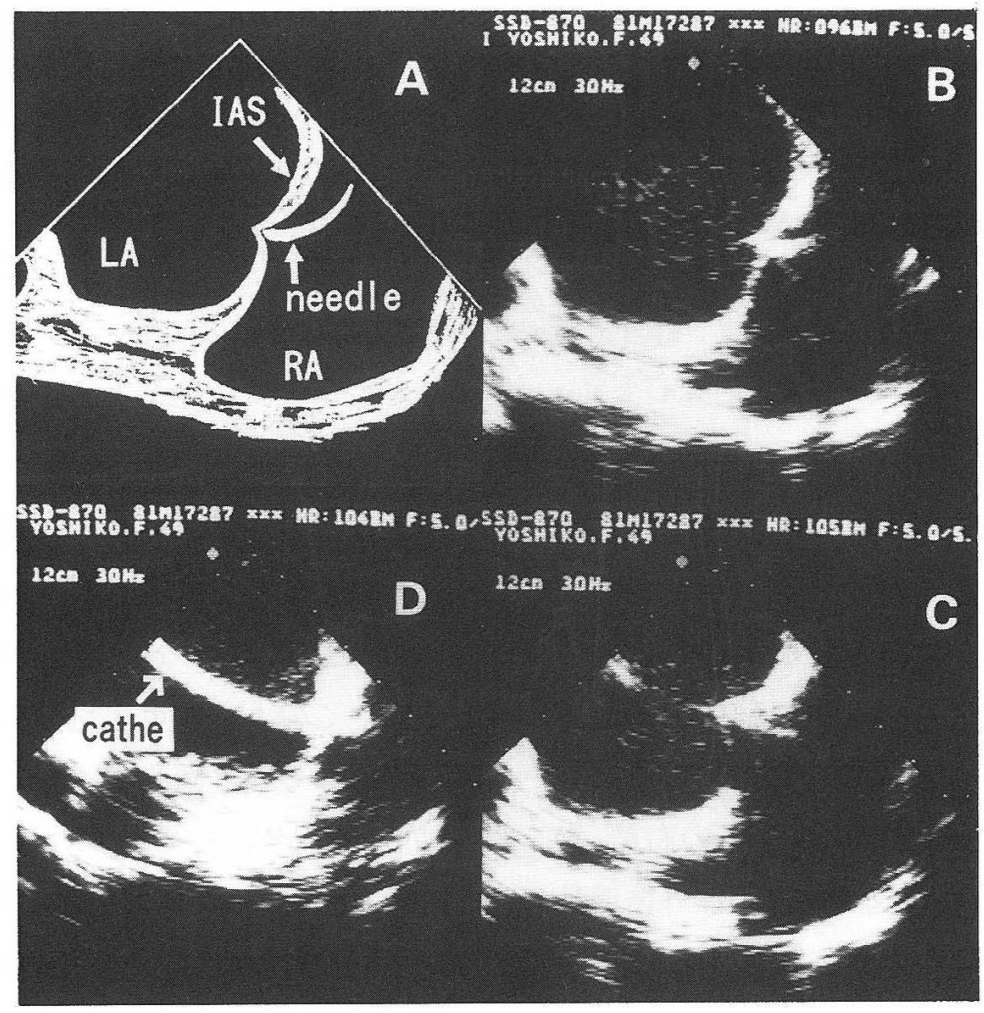

Fig. 3. Biplane transesophageal echocardiographic scheme and images of the interatrial septum at the time of Brockenbrough septal puncture.

に挿入可能な左房脱血用カニューレを用いた $\mathrm{AAB}$ を試みた。1 例を除いた全例にVABが施行されてお り, 血行動態の変化を尿量, 心エコーによる壁運動, left ventricular ejection fraction (以下 LVEF と略
す)などで観察した。

Fig. 1 は AAB と VAB のシェーマである。左房か ら引かれた血液は遠心ポンプにて大腿動脈に送血さ れる。左房脱血用カニューレは, サイズは $18 \mathrm{~F}$ で先 


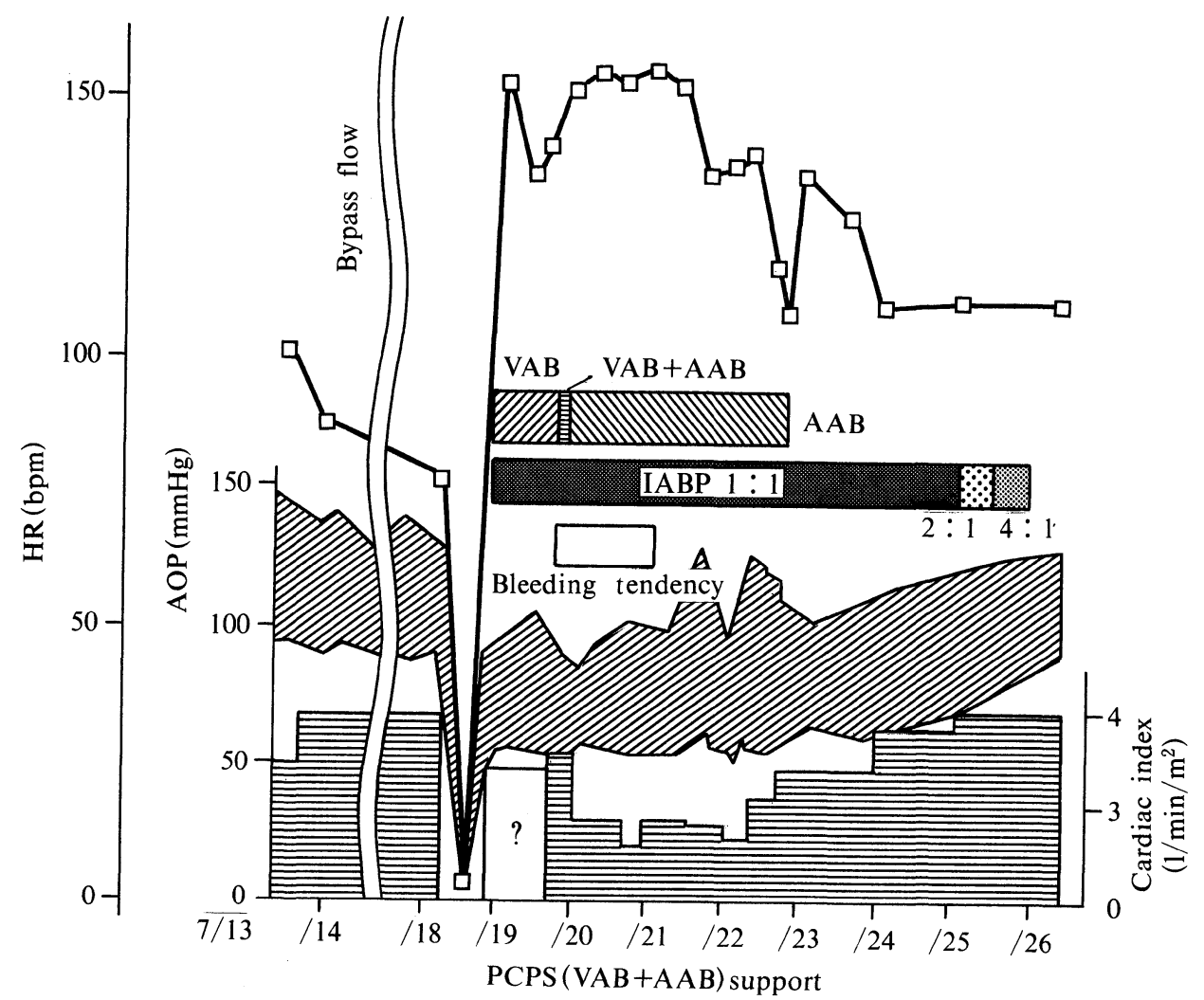

Fig. 4. Changes in hemodynamic parameters and bypass flow during VAB and AAB support.

$\square-\square=\mathrm{HR}$

端から $40 \mathrm{~mm}$ までに直径 $2 \mathrm{~mm}$ の側孔を 20 個有す るアングル型である。右房脱血用カニューレは，サ イズは $18 \mathrm{~F}$ で先端から $100 \mathrm{~mm}$ までに直径 $2 \mathrm{~mm}$ の 側孔を 20 個有する直型である。

大腿動脈送血用カニューレのサイズは両方とも 14Fである。これらはいずれもメディキット社製で ある（Fig. 2)。脱血カニューレの左房内插入法につ いては，われわれは，経皮的経静脈的僧帽弁交連裂 開術（以下 PTMC と略す）にて biplane 経食道心工 コー図をガイドとした安全な中隔穿刺法を検討して きており，これに沿って脱血カニューレを大腿静脈 より心房中隔を経て左心房に㭔入した $(\text { Fig. 3 })^{8,9)}$ 。

循環改善の指標としては, AAB 插入により速や かに Forrester 4 群が 1 群に移行, 体血圧が 90 $\mathrm{mmHg}$ 以上，尿量が $0.5 / \mathrm{hr} / \mathrm{kg}$ を保てるようになっ たものを $(+)$, これらの一部を満たした場合を $(+)$, いずれの効果をも得られなかった場合を（一）とし
た。

\section{結果}

症例 $1: 43$ 歳, 男性。

AMI そて direct purcutaneous transluminal coronary angioplasty を施行（前下行枝 (LAD) \#6の 100\%閉塞を 50\%以下として終了), 経過は良好であ ったが，7病日に病棟内にて突然ショック状態とな った。心電図には不整脈や明らかな ST 変化を認め なかった。CCU 搬入直後心停止となり心肺蘇生開 始するが，直流除細動（DC）不応性心室細動にて蘇 生困難なため VAB を開始したところ, 血行動態が 維持できるようになって蘇生に成功, さらに IABP を挿入して after-load の軽減を試みた。その後 VAB の離脱を試みたが成功せず，時間の経過とともに顕 著な出血傾向がみられてきたために，へパリンの減 量と血行動態の維持の両面を考慮して $\mathrm{AAB}$ を装着 


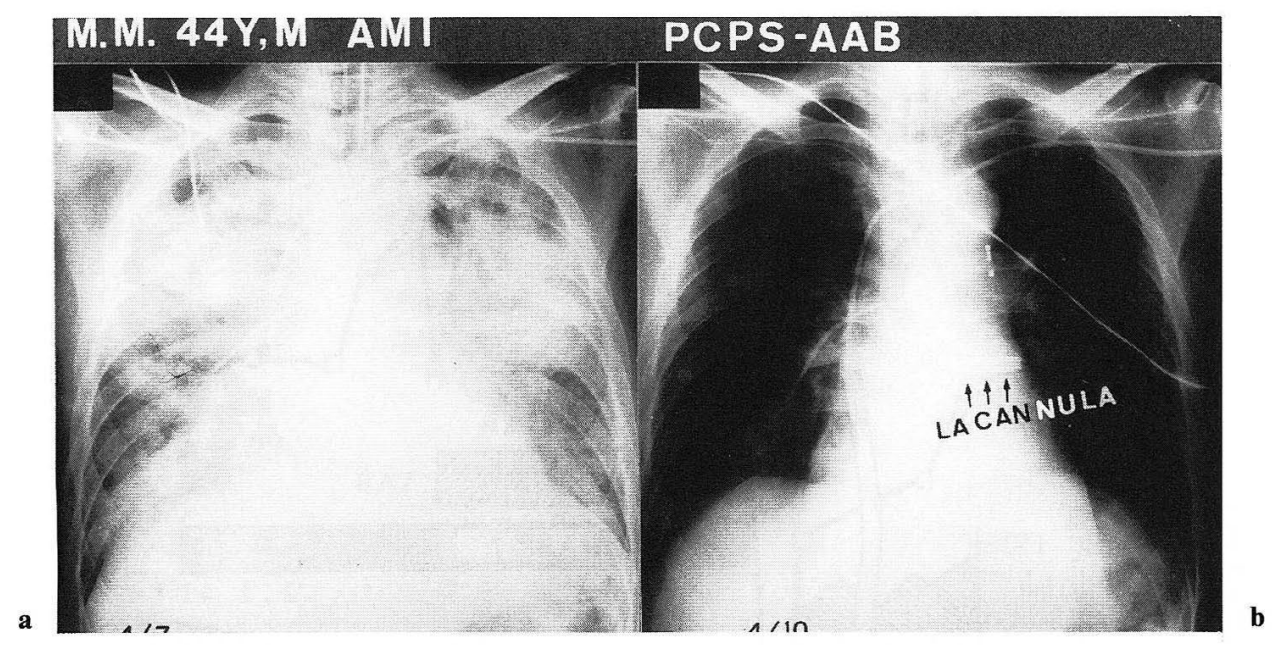

Fig. 5. Chest roentgenogram.

a : On admission, a patient who had been dependent on IABP for 1 month.

b : 3 days after initiating treatment with $A A B$.

した。装着後出血傾向は漸減，その後の血行動態の 維持も容易で $\mathrm{AAB}$ の離脱は順調であった

(Fig. 4)。

症例 $2: 44$ 歳, 男性。

AMI てて近医に緊急入院, 心原性ショックにて IABP 挿入される（LAD＃6 100\%，他にも陳旧性心 筋梗塞責任病変である右冠動脈＃2 100\%, Cx \# 13 99\%の 3 枝病変)。その後 35 病日間 IABP 作動させ るも心エコーでLVEF 15\%, 肺うっ血著明 (Fig. 5a), さらに無尿となり当院緊急転院される。重症左 心不全と判断して最初から $\mathrm{AAB}$ を開始した。AAB 装着後に胸部 X 線上の肺うつ血は軽快 (Fig. 5b)，工 コー上は LVEF１5\%が 43\%に，肺動脈楔入圧は 28 $\mathrm{mmHg}$ が $12 \mathrm{mmHg}$, 尿量は $4 \mathrm{ml} / \mathrm{hr} / \mathrm{kg}$ と著明改善 を認めて外科手術に移行できた。しかし術後 multiple organ failureにて，これを失っている。

Table 1 は，AAB 挿入を試みたが挿入できずに $\mathrm{VAB}$ 補助のみであった 1 例を含む 5 症例のまとめ である。AAB の最終的な効果判定となる生命予後 については, 生存例は 1 例のみであった。

\section{考案}

今月, 重症心不全の内科治療のなかで機械的補助
循環法はきわめて強力な strategy である。補助循環 の手順としてはまずIABP を実施するが，IABP は 血圧の時相を変えることを主眼とした圧力補助であ るので，その心臓補助効果に限界があることも事実 である。

近年, IABP にて効果が得られない場合には通常 VABが追加されている。流量補助を主眼とした VAB は, 1983 年 Phillips $ら^{10)}$ が経皮的動静脈力二 ュレーションシステムを開発したところから始ま り，その後の改良により最近ではとくに蘇生困難な 心停止に対する迅速な対応にきわめて優れた方法と なっている。しかし VAB は回路内に人工肺を含む ため十分な抗凝估剤の投与を行う必要があり, 出血 傾向の出現する率が高く, またガス交換能の経時的 低下が生ずる問題がある。

一方左心バイパスは，人工肺を必要とせずより少 ない抗凝固㶡の投与で済むので，出血傾向の出現が 少なくガス交換能の経時的低下も生じないという利 点があり,さらに重症低心拍出量心筋梗塞などでは, 直接左室の減圧を行い得て有効に左室仕事量を軽減 させるといつた大きな利点を有している。

実際，われわれの行った動物実験では，補助循環 なしで雑種成犬の LAD Cx を結禁した場合平均 3 分後に心室細動となり, 再灌流後の DC にても除細 
Table 1. Clinical results of 5 patients treated with $\mathrm{AAB}$ and $\mathrm{VAB}$ support.

\begin{tabular}{cclcccc}
\hline Case & Age/Sex & \multicolumn{1}{c}{ Diagnosis } & Mode & Hemodynamic improvement* $^{*}$ & Weaning & Result \\
\hline 1 & $43 / \mathrm{M}$ & Cardiac arrest & VAB $+\mathrm{AAB}$ & + & + & Survival \\
2 & $44 / \mathrm{M}$ & Cardiogenic shock & $\mathrm{AAB}$ & + & $+\rightarrow$ ope $)$ & Death \\
3 & $54 / \mathrm{M}$ & Cardiac arrest & VAB** & - & - & Death \\
4 & $64 / \mathrm{M}$ & Cardiac arrest & VAB $+\mathrm{AAB}$ & + & - & Death \\
5 & $70 / \mathrm{M}$ & Cardiogenic shock & VAB $+\mathrm{AAB}$ & + & + & + Death \\
\hline
\end{tabular}

* Assessment of clinical utility of AAB support.

** The interatrial septal puncture was unsuccessful, despite attempting AAB support.

+ Distinctly improved hemodynamic parameter, as below, after treatment with AAB.

Forrester group $4 \rightarrow 1$, systolic pressure over $90 \mathrm{mmHg}$ and urine volume stable at $0.5 \mathrm{ml} / \mathrm{hr} / \mathrm{kg}$.

+ Moderately improved hemodynamic parameter, as below.

Forrester group $4 \rightarrow 1$ or systolic pressure over $90 \mathrm{mmHg}$ or urine volume stable at $0.5 \mathrm{ml} / \mathrm{hr} / \mathrm{kg}$.

- No improvement in afore mentioned conditions.

動されなかったが，補助循環下では 70〜 $80 \mathrm{mmHg}$ の血圧が維持され，20 分以上は心室細動とはならな かった。この傾向はVAB に比較して $\mathrm{AAB} て ゙$ 明らか であった7)。また症例 1 で, VAB下の強力な抗凝固 療法により出血傾向が著しくなりコントロールが困 難となったが, AAB 移行によりその出血傾向は認 められなくなっている。

しかし，このように臨床的価值の高い左心バイパ スも，その装着には外科医による開胸下での left ventricular assist system の装着法か, 経皮的插入法 では X 線透視下に左房内に脱血カニューレの插入 が必要であり, 穿刺の際の心臓壁穿通の危険が常に 問題となり, 内科医のみでの $\mathrm{AAB}$ 装着を困難とし ていた。

これに対してわれわれは，PTMC 施行時にbiplane 経食道心エコーガイド下に心房中隔穿刺をす ることが安全かつ容易であることを報告してきてお $\eta^{8)}$,この技術を $\mathrm{AAB}$ の臨床に用いてその安全性を 確認した ${ }^{9)}$ 。われわれの AAB は，内科医のみで装着 が可能で重症左心不全に用いられるだけではなく, 従来 IABP の適応とはならなかった重症大動脈弁閉 鎖不全症や解離性大動脈瘤の心不全に対しても理論 上応用可能と考えている。

最後に, 今回 $\mathrm{AAB}$ が強力な左心補助手段にもか かわらず 4 症例中 1 症例のみしか生存に結びつけら
れなかったことについて, $\mathrm{AAB}$ は強力な左心補助 手段ではあるが，生存に結びつけるためには AAB の速やかな導入とこれに続いての percutaneous transluminal coronary angioplastyあるいは coronary-aortic bypass graft（症例によっては弁置換術） といった抜本的な冠動脈血行再建術が速やかに行わ れるという条件が必要と考えられる。

\section{文献}

1）富田喜文, 高野照夫：大動脈内バルーンパンピング. 集中治療 $1991 ; 3: 223-9$.

2）許俊鋭, 尾本良三, 横手祐二, 他：循環補助の進歩 一静・動脈バイパス法一。集中治療 $1991 ； 3$ ： 205-11.

3) Shawl FA, Domanski MJ, Hernandez TJ, et al: Emergency percutaneous cardiopulmonary bypass support in cardiogenic shock from acute myocardial infarction. Am J Cardiol 1989; 64: 967-70.

4）服部良二, 魏啓明, 井村正史, 他：急性左心不全に 対するVAバイパスの循環補助効果に関する実験 的検討. 日胸外会誌 $1987 ; 35: 483-90$.

5) Hatano $T$, Omoto R, Ueda $K$, et al : The comparison of hemodynamic effects of concomitant use of intraaortic balloon pumping and veno-arterial bypass with atrio-arterial bypass. Jpn Heart J $1980 ; 21$ : 273-9.

6）腰塚誠二, 許俊鋭, 半田宣宏, 他：急性僧帽弁逆流 に対する LAVD 補助効果の実験的検討。人工臟器 $1990: 19: 38-41$.

7）元山猛, 許俊鋭, 宮本直政, 他：急性心筋梗塞に上 る心不全に対する各種経皮的補助循環の臨床的・実 
験的有用性の検討. 日本心臟病学会 40 回学術集会抄 録集 $1992 ；$ Suppl：83.

8）元山猛, 許俊鋭, 宮本直政, 他：Bi-plane 経食道工 コーガイドによる経皮的僧帽弁交連裂開術一安全な 心房中隔穿刺の臨床的意義について一。 日本超音波 医学会 57 回研究発表講演論文集 $1990 ； 313-4$.
9）許俊鋭，野田裕幸，元山猛，他：経食道心エコーガ イド下心房中隔穿刺による経皮経心房中隔的左房脱 血管捰入法の検討. 人工臟器 $1992 ; 21 ; 347-52$.

10) Phillips SJ, Ballentine B, Slonine D, et al:Percutaneous initiation of cardiopulmonary bypass. Ann Thorac Surg 1983；36:223-5.

\section{ABSTRACT \\ Utility of Percutaneous Cardiopulmonary Support by Left Atrial-Aortic Bypass in Heart Failure \\ Toshihiro Muramatsu, Takeshi Motoyama, Shunei Kyo, Naomasa Miyamoto Hiroshi Imafuku, Ryozo Omoto and Yutaka Dohi \\ Heart Institute, Saitama Medical School}

This study was designed to evaluate the efficacy of original percutaneous left heart bypass (left atrial-aortic bypass : $\mathrm{AAB}$ ) on 5 patients (three with cardiac arrest, two with cardiogenic shock) with heart failure caused by acute myocardial infarction. First, the insertion procedure for the dehemaize tube into the left atrium was performed easily and safely under transesophageal echo monitoring. All patients had already been treated with intra-aortic balloon pumping (IABP) and percutaneous veno-arterial bypass (VAB), but without effect. Two of three patients with cardiac arrest were also treated with $\mathrm{AAB}$, producing prompt hemodynamic improvement. One recovered secondary to this hemodynamic improvement. Two patients with cardiogenic shock were treated with AAB, and hemodynamics also improved. In particularly, a patient who had been dependent on IABP for 1 month, recovered from cardiogenic shock in response to $\mathrm{AAB}$ treatment within 3 days and subsequently underwent arteriocoronary bypass. In conclusion, VAB is useful for prompt treatment of cardiac arrest, while AAB is very useful for IABP and $\mathrm{VAB}$ is ineffective for heart failure.

(JJAAM $1993 ; 4: 605-10)$

Key Words : percutaneous left heart bypass, transesophageal echocardiography, percutaneous veno-arterial bypass, intra-aortic balloon pumping, left heart failure

Received for publication on March 9, 1993 (93-016) 